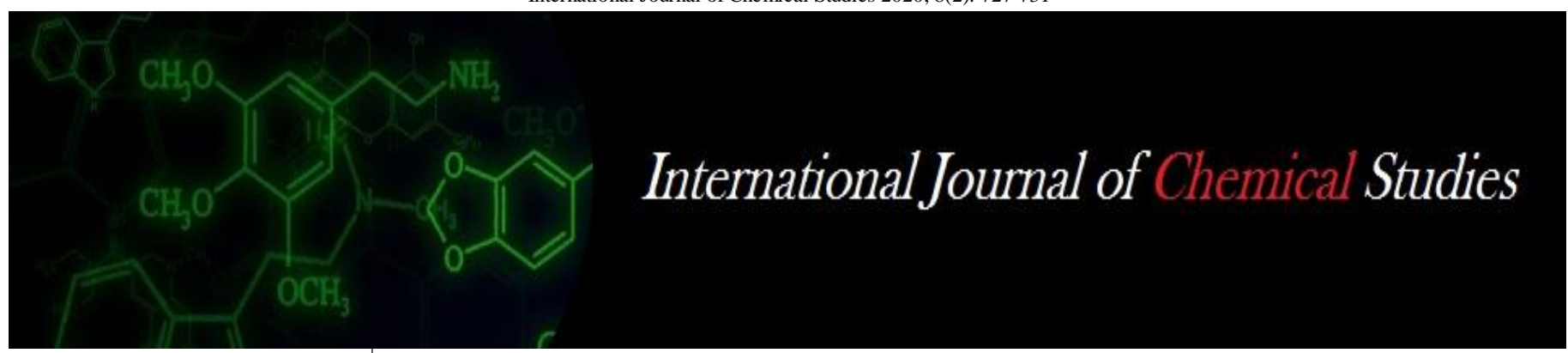

P-ISSN: 2349-8528

E-ISSN: 2321-4902

www.chemijournal.com

IJCS 2020; 8(2): 727-731

(C) 2020 IJCS

Received: 24-01-2020

Accepted: 28-02-2020

\section{B Devojee}

M. Tech student, Department of

Farm Machinery and Power

Engineering, CTAE, Udaipur,

Rajasthan, India

\section{SS Meena}

Assistant Professor, Department

of Farm Machinery and Power

Engineering, CTAE, Udaipur,

Rajasthan, India

\section{AK Sharma}

Professor, Department of Farm

Machinery and Power

Engineering, CTAE, Udaipur,

Rajasthan, India

\section{Agarwal}

Assistant Professor, Department of Mechanical Engineering, CTAE, Udaipur, Rajasthan, India
Corresponding Author: B Devojee

M. Tech student, Department of Farm Machinery and Power

Engineering, CTAE, Udaipur, Rajasthan, India

\section{Performance evaluation of weeder by number of blades per flange in chilli crop}

\author{
B Devojee, SS Meena, AK Sharma and C Agarwal
}

DOI: https://doi.org/10.22271/chemi.2020.v8.i2k.8855

\begin{abstract}
India is a vast country with 329 million hectares of geographical area with agriculture still as a main occupation of 70 per cent of Indian population. Weeding is an essential operation in agriculture to prevent undesired species from growing and consuming the key resources (i.e. water, minerals, soil and sunlight) and thereby compromising crop yield. Farmers spend a large amount of time and money managing weeds. Weeds are always associated with human endeavors and because huge reductions in crop yields, increase cost of cultivation, reduce input efficiency, interfere with agricultural operations, impair quality, act as alternate hosts for several insect pests, diseases and nematodes. At a conservative estimate, an amount of Rs.100 billion is spent on weed management annually in India, in arable agriculture alone. The rotary type weeder stirs the soil more accurately, disturb the weed root and remove them from soil. In addition this helps in keeping the soil in loose condition for proper aeration. The major advantage of rotary power weeder is power being used for rotary weeder blades requires less draft and improved field performance. A portable knapsack power weeder was developed with width of cut was 25 $\mathrm{cm}$ and tested in chilli crop with number of blades per flange (2, 4 and 6). Operational speed, actual field capacity, field efficiency, weeding efficiency, plant damage, actual working depth of cut, fuel consumption, performance index of (2,4,6 blades per flange) was $0.43,0.40$ and $0.38 \mathrm{~m} / \mathrm{s}, 0.029,0.027$ and $0.025 \mathrm{ha} / \mathrm{h}, 77.3,72.1$ and 66.1 per cent, 79.9, 83 and 85.2 per cent, 5.03, 4.73 and 3.30 per cent, $3.46,4.16$ and $4.60 \mathrm{~cm}, 0.64,0.71$, and $0.76 \mathrm{l} / \mathrm{h}, 132,128$ and 123 .
\end{abstract}

Keywords: Number of blades per flange, operational speed, actual field capacity, weeding efficiency

\section{Introduction}

One third of the cost of cultivation is spent on weeding alone when carried out with the manual labour. Manual weeding requires huge labour force and accounts for about 25 per cent of the total labour requirement (900-1200 man-hours/hectare). Use of herbicides will have residual effect and change in quality of soil and the chemicals used in weed killers cause damage to the environment and to the health of people who come into contact with them. Tractor operated weeding implements can save about 75 per cent time and 20 per cent cost as compared to bullock drawn methods. But there is uncovered headland and tractor hiring charges will be crucial input cost which may vary according to the season. The rotary type weeder stirs the soil more accurately, disturb the weed root and remove them from soil. In addition this helps in keeping the soil in loose condition for proper aeration. The major advantage of rotary power weeder is power being used for rotary weeder blades requires less draft and improved field performance.

The rotary type weeder stirs the soil more accurately, disturb the weed root and remove them from soil. In addition this helps in keeping the soil in loose condition for proper aeration. The major advantage of rotary power weeder is power being used for rotary weeder blades requires less draft and improved field performance. Several weeders are available which run by tractor or power tiller, these are large in size cannot work for low inter row spaced crops.

\section{Material and Methods}

\section{Components of weeder}

The portable knapsack power weeder has consists of following components. They are engine, Flexible drive shaft, handle, worm gear box, rotor shaft, flanges, blades, blade cover, and transportation wheels. 
Table 1: Specifications of developed portable knapsack power weeder

\begin{tabular}{|c|c|c|}
\hline S. No. & Specification & Value \\
\hline 1 & $\begin{array}{l}\text { Number of engine } \\
\text { cylinder }\end{array}$ & 1 \\
\hline 2 & $\begin{array}{c}\text { Engine maximum power } \\
\text { at } 6500 \mathrm{rpm}\end{array}$ & $1.25 \mathrm{~kW}$ \\
\hline 3 & Weeding width & $25 \mathrm{~cm}$ \\
\hline 4 & No. of Blades per flange & $2,4,6$ \\
\hline 5 & Rotor speed & $185 \mathrm{rpm}$ \\
\hline 6 & Weeding depth & $3-5 \mathrm{~cm}$ \\
\hline 7 & Power transmission & Lightweight aluminum gear box \\
\hline 8 & Fuel tank capacity & $0.9 \mathrm{~L}$ \\
\hline 9 & Fuel & $\begin{array}{l}\text { Petrol mixed with lubricating oil (1 } \\
\text { liter of petrol with } 30 \mathrm{ml} \text { of oil) }\end{array}$ \\
\hline 10 & Material of blade & Spring steel-L-type blade \\
\hline 11 & Total weight & $11 \mathrm{~kg}$ \\
\hline
\end{tabular}

\section{Experimental details}

Power weeder with different numbers of blades were selected as treatments

$\left(\mathrm{T}_{1}\right)$ Power weeder-2 blades per flange, all are at $180^{\circ}$ to each other

$\left(\mathrm{T}_{2}\right)$ Power weeder-4 blades per flange, all are at $90^{\circ}$ to each other

$\left(\mathrm{T}_{3}\right)$ Power weeder- 6 blades per flange, all are $60^{\circ}$ to each other

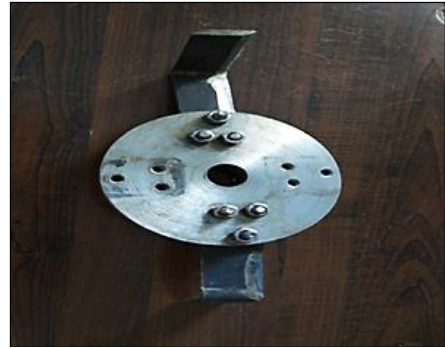

Fig 1: Flange with 2 blades

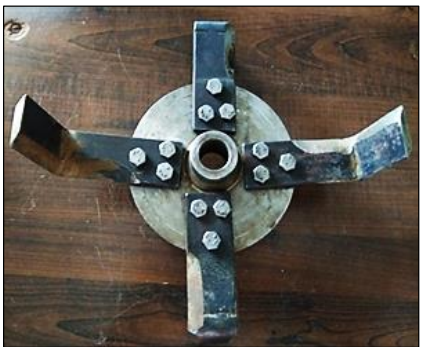

Fig 2: Flange with 4 blades

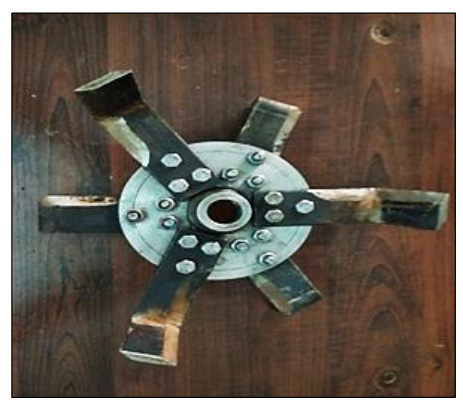

Fig 3: Flange with 6 blades

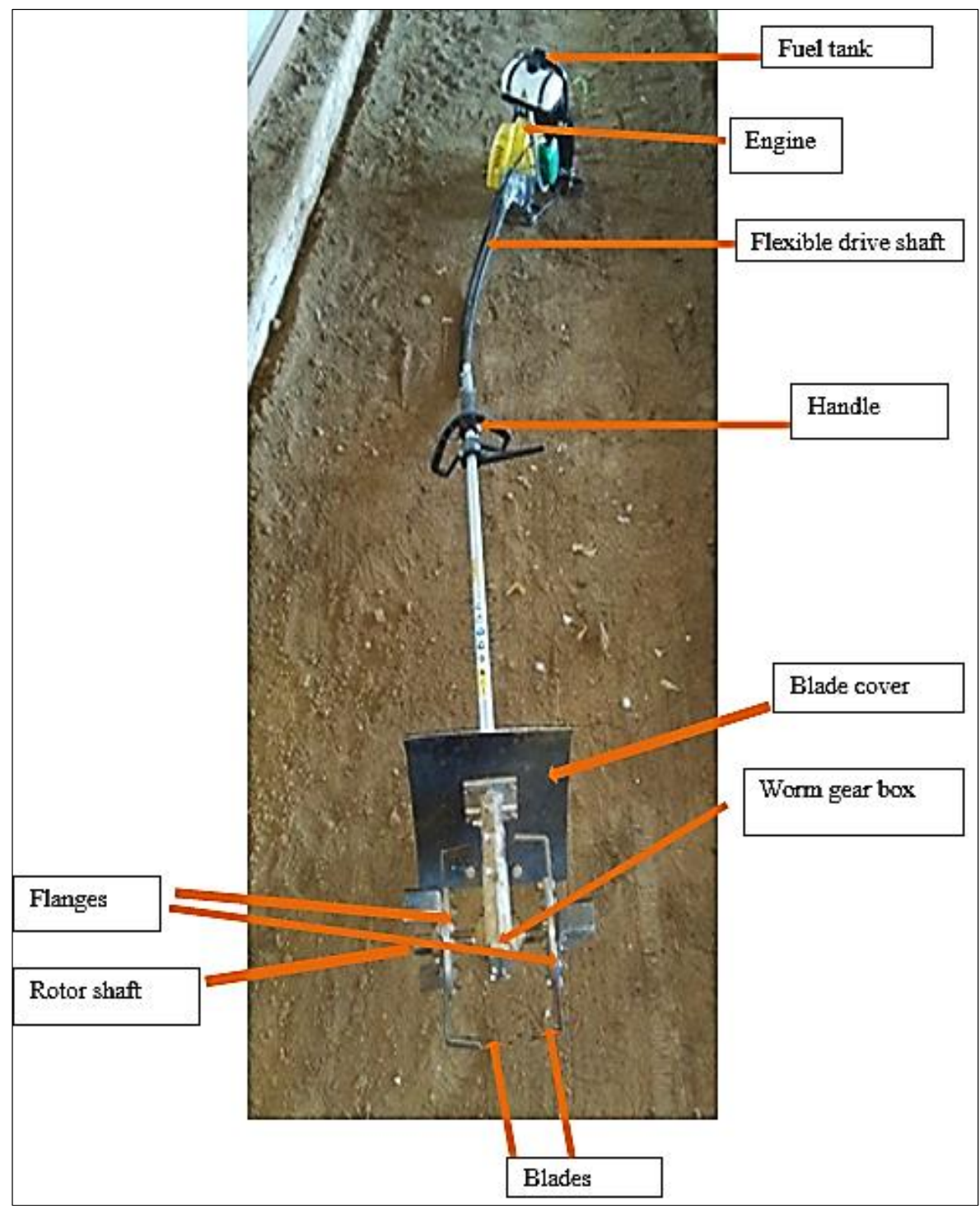

Fig 4: Portable knapsack power weeder 


\section{Performance evaluation of portable knapsack power weeder}

After completion of the development of power weeder, the field experiments were conducted to evaluate the performance of the machine.

\section{Speed of operation}

The speed of operation was calculated by observing the distance traveled and the time taken as

$S=\frac{L}{t}$

Where,

$\mathrm{S}=$ Forward speed of operation, $\mathrm{m} / \mathrm{s}$

$\mathrm{L}=$ Distance traveled, $\mathrm{m}$

$\mathrm{t}=$ Time taken, $\mathrm{s}$

\section{Effective working depth of cut}

The depth of cut of the machine with different blades was measured in the field by measuring the depth of soil layer tilled by the blade in a row. The depth of the weeding was measured by measuring scale in different rows at different places. Average of 3 observations was taken as depth of weeding and expressed in $\mathrm{cm}$.

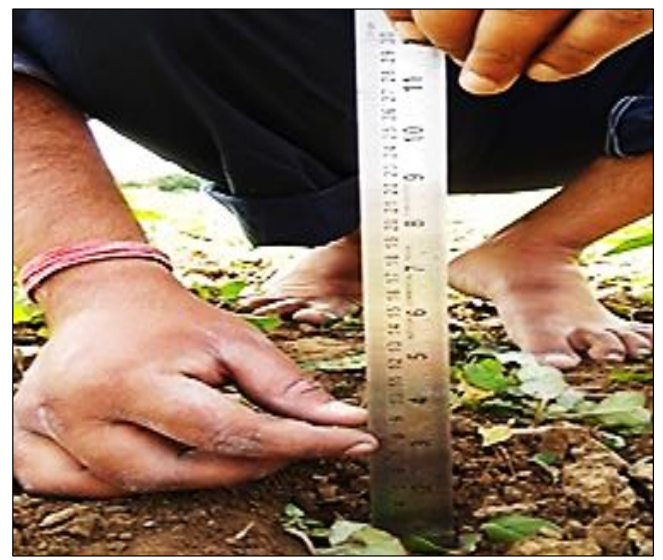

Fig 5: Measurement of depth of cut

\section{Effective working width of cut}

The width of cut of the machine with different blades was measured in the field by measuring scale in different rows at different places.

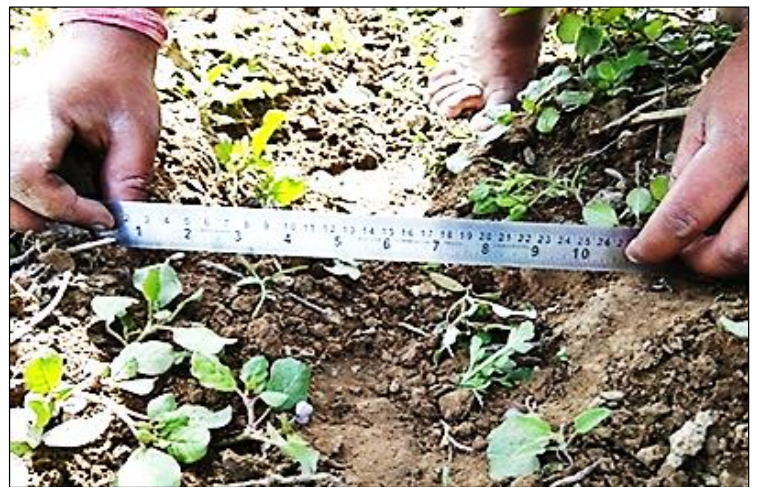

Fig 6: Measurement of width of cut

\section{Theoretical field capacity}

Theoretical field capacity of the machine is the rate of field coverage of the machine that based on 100 percent of time at the rated speed and covering 100 per cent of its rated width. It is expressed as hectare per hour and determined as follows (Kepner et al., 1978) ${ }^{[3]}$

Theoretical field capacity, ha $\mathrm{h}^{-1}=\frac{\operatorname{Width}(\mathrm{m}) \times \operatorname{Speed}(\mathrm{km} / \mathrm{h})}{10}$

\section{Effective field capacity}

The effective field capacity of power weeder was computed by recording the area weeded during each trial run in a given time interval. It is dependent upon speed of operation. With the help of stopwatch, time was recorded for respective trial run along with area covered.

Effective field capacity, ha $\mathrm{h}^{-1}=\frac{\text { Area covered (ha) }}{\text { Time required (h) }}$

Field efficiency

Field efficiency is the ratio of effective field capacity to the theoretical field capacity, Expressed as percentage

Field efficiency, per cent $=\frac{\text { Effective field capacity }\left(\mathrm{ha} \mathrm{h}^{-1}\right)}{\text { Theoretical field capacity }\left(\mathrm{ha} \mathrm{h}^{-1}\right)} \times 100$

\section{Weeding efficiency}

Weeding efficiency is the ratio between the numbers of weeds removed by power weeder to the number of weeds present in a unit area and is expressed as a percentage. The samplings were done by quadrant method, by randomly selection of spots by a square quadrant of 1 square meter (Tajuddin, 2006) ${ }^{[8]}$. Higher the value of weeding efficiency better is the weeder performance.

Weeding efficiency, per cent $=\frac{\mathrm{W}_{1}-\mathrm{W}_{2}}{\mathrm{~W}_{1}} \times 100$

Where,

$\mathrm{W}_{1}=$ Number of weeds counted in a unit area before weeding operation

$\mathrm{W}_{2}=$ Number of weeds counted in same unit area after weeding operation

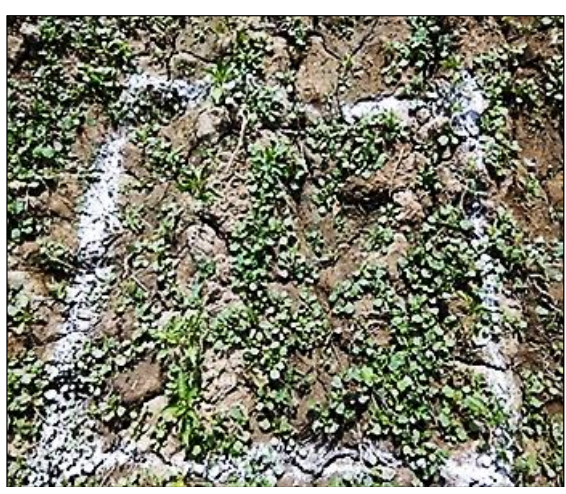

Fig 7: Chilli crop before weeding operation

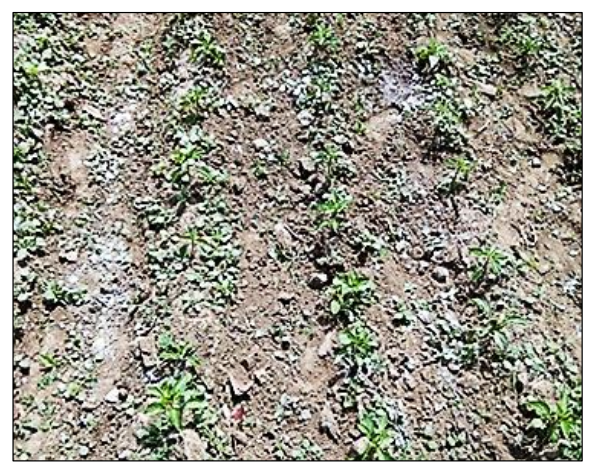

Fig 8: Chilli crop after weeding operation 


\section{Plant damage}

Plant damage is the ratio of the number of plants damaged after operation in a row to the number of plants present in that row before operation. It was calculated by the following formula (Yadav and Pund, 2007) ${ }^{[9]}$. It is expressed in percentage.

Plant damage $(\%)=1-\frac{\mathrm{Q}}{\mathrm{P}} \times 100$

Where,

$\mathrm{Q}=$ Number of plants in a $10 \mathrm{~m}$ row length of field after weeding

$\mathrm{P}=$ Number of plants in a $10 \mathrm{~m}$ row length of field before weeding

\section{Performance index}

Performance of the weeder was assessed through performance index (PI) by using the following relation as suggested by (Srinivas et al., 2010).

Performance index $=\frac{\mathrm{FC} \times(100-\mathrm{PD}) \times \mathrm{WE}}{\text { Engine power }(\mathrm{hp})}$

Where,

$\mathrm{FC}=$ Field capacity, ha $\mathrm{h}^{-1}$

$\mathrm{PD}=$ Plant damage, per cent

$\mathrm{WE}=$ Weeding efficiency, per cent

\section{Fuel consumption}

The fuel consumption has direct effect the economics of the power weeder. It was measured by top fill method. The fuel tank was filled to full capacity before and after the test. After completion of test operation, amount of fuel required to top fill again is the fuel consumption for the test duration. It was expressed in litre per hour.

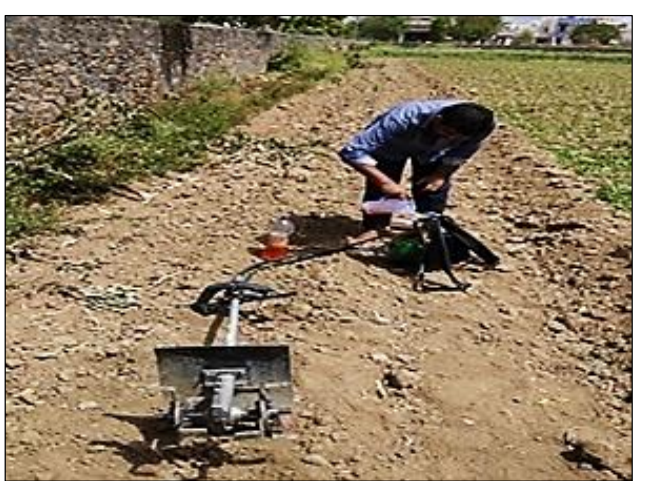

Fig 9: Measurement of fuel consumption

Fuel consumption $=\frac{\text { Fuel } \text { consumption }, \mathrm{L}}{\mathrm{Time} h \mathrm{hr}}$

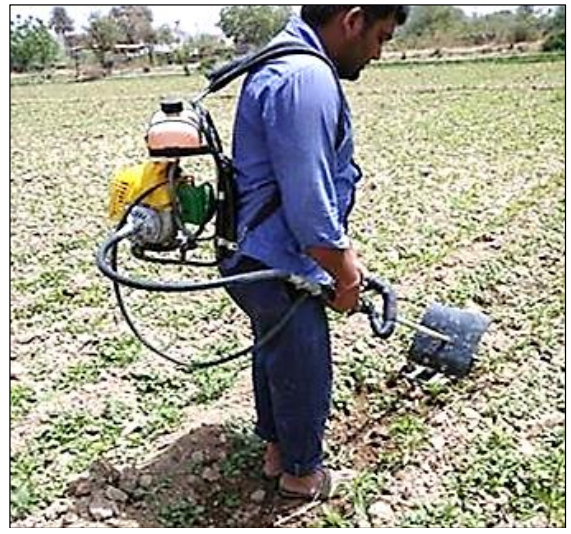

Fig 10: Weeder testing in chilli field

\section{Instrumentations}

Stop watch: A stop watch was used to measure time required for one turn and turning of a weeder. Time was generally measured in second and further calculated to minutes and hours as per requirement.

Measuring tape: A measuring tape of $30 \mathrm{~m}$ was used for measuring and marking in the field. A steel foot rule was also used for measuring depth of operation, height of crop and height of weeds.

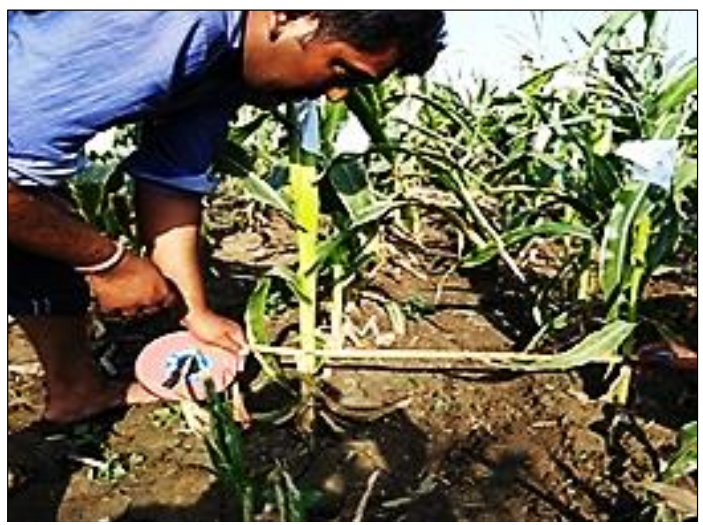

Fig 11: Measuring of row to row spacing

Tachometer: Mechanical tachometer was used to measure the rpm of rotor shaft.

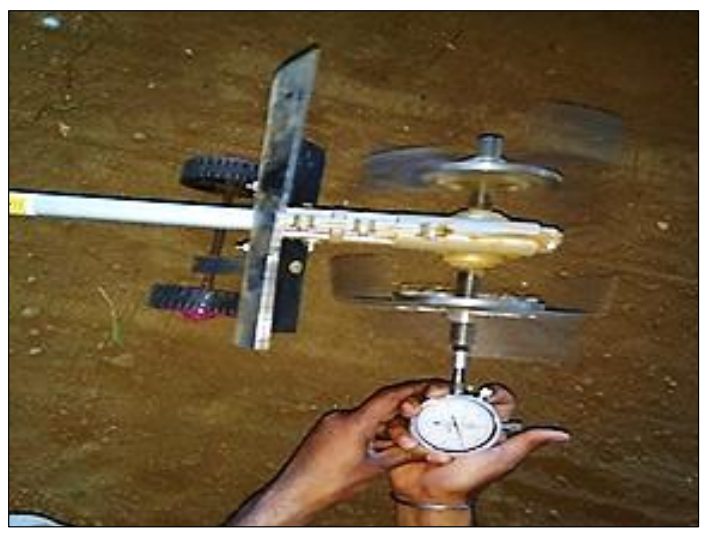

Fig 12: Measurement of rpm of rotor shaft with tachometer

\section{Result and Discussion \\ Speed of operation}

Speed of operation of the weeder with different blades $(2,4$, and 6) was determined. Maximum and minimum speed of operation of the weeder was $0.43 \mathrm{~m} / \mathrm{s}$ with 2 blades and 0.38 $\mathrm{m} / \mathrm{s}$ with 6 blades, whereas $0.40 \mathrm{~m} / \mathrm{s}$ with 4 blades.

\section{Effective working depth of cut}

The effective working depth of cut of weeder for different blades $(2,4$, and 6$)$ was determined. The data reveals that, the maximum and minimum depth of cut of weeder was $4.60 \mathrm{~cm}$ with 6 blades and $3.46 \mathrm{~cm}$ with 2 blades, whereas $4.16 \mathrm{~cm}$ with 4 blades.

\section{Effective working width of cut}

The width of cut of the weeder with different blades was measured in the field by observing the strip of soil and weeds cut in a row. The effective width of cut of the weeder was found as $25 \mathrm{~cm}$. 


\section{Theoretical field capacity}

The theoretical field capacity of the weeder with different blades $(2,4$, and 6$)$ was measured. The width of cut of the weeder was $25 \mathrm{~cm}$ and speed of operation was assumed 1.5 $\mathrm{km} / \mathrm{h}$ for all blades (2, 4 and 6). The theoretical field capacity of the weeder for all blades was $0.0375 \mathrm{ha} / \mathrm{h}$.

\section{Effective field capacity}

The effective field capacity of the weeder with different blades $(2,4$, and 6) was measured. Higher the value of field capacity better was the weeder performance. The data reveals that, the maximum and minimum effective field capacity of weeder was $0.029 \mathrm{ha} / \mathrm{h}$ with 2 blades and $0.025 \mathrm{ha} / \mathrm{h}$ with 6 blades, whereas $0.027 \mathrm{ha} / \mathrm{h}$ with 4 blades.

\section{Field efficiency}

The field efficiency of the weeder with the different blades $(2$, 4, and 6) was measured. The data reveal that the maximum and minimum field efficiency of weeder was 77.3 per cent with 2 blades and 66.1 per cent with 6 blades, whereas 72.1 per cent with 4 blades. The actual field capacity of weeder increases with increasing field efficiency and decreases with decreasing field efficiency.

\section{Weeding efficiency}

The weeding efficiency of the weeder with the different blades $(2,4$, and 6$)$ was measured. The data reveal that the maximum and minimum weeding efficiency of weeder was 85.2 per cent with 6 blades and 79.9 per cent with 2 blades, whereas 83 per cent with 4 blades. In 6 blades, depth of cut increases as speed of weeder reduces, weeding efficiency increases whereas comparing with 2 blades depth of cut decreases and speed increases, weeding efficiency decreases. Weeding efficiency depends on the number of weeds presents in the crop. The power weeder has the capacity to till the weeder blade cut the soil to desired depth. Therefore, it works much better between two rows for control of weeds. The rotating blade of power weeder may cause damage to the plants if it is brought nearer to the rows. Considering this limitation of weeder, it gives lower weeding efficiency 85.2 percent. The power weeder gives better performance even in later stages of weeding. It was clear that, as the depth of operation increases, the weeding efficiency increases.

\section{Plant damage}

The plant damage of the weeder with the different blades (2, 4 , and 6) was measured. The data reveal that the maximum and minimum weeding plant damage of weeder was 5.03 per cent with 2 blades and 3.30 per cent with 6 blades, whereas 4.73 per cent with 4 blades. Maximum plant damage was observed with 2 blades as it runs with high speed and jerks. Comparing with 6 blades, rotor moving with low speed and depth of cut increases and no jercks was observed and thereby lower plant damage was observed.

\section{Fuel consumption}

Fuel consumption of the power weeder was calculated by topping method. The maximum fuel consumption was found with 6 blades as $0.76 \mathrm{l} / \mathrm{h}$ due to more depth of cut $(4.60 \mathrm{~cm})$ and minimum fuel consumption was found in chilli crop with 2 blades as $0.64 \mathrm{l} / \mathrm{h}$ due to low depth of cut $(3.46 \mathrm{~cm})$. Whereas with 4 blades the fuel consumption was $0.71 \mathrm{l} / \mathrm{h}$.

\section{Performance index}

Maximum and minimum performance index of power weeder was 132 with 2 blades and 123 with 6 blades respectively. Whereas with 4 blades the performance index was 128 .

Table 2: The plant damage of the weeder with the different blades

\begin{tabular}{|c|c|c|c|c|}
\hline S. No & Parameter & 2 Blade & 4 Blade & 6 Blade \\
\hline 1 & Operational speed, $(\mathrm{m} / \mathrm{s})$ & 0.43 & 0.40 & 0.38 \\
\hline 2 & Actual field capacity, $(\mathrm{ha} / \mathrm{h})$ & 0.029 & 0.027 & 0.025 \\
\hline 3 & Field efficiency, $(\%)$ & 77.3 & 72.1 & 66.1 \\
\hline 4 & Weeding efficiency, $(\%)$ & 79.9 & 83 & 85.2 \\
\hline 5 & Plant damage, $(\%)$ & 5.03 & 4.73 & 3.30 \\
\hline 6 & Actual working depth of cut, $(\mathrm{cm})$ & 3.46 & 4.16 & 4.60 \\
\hline 7 & Fuel consumption, $(1 / \mathrm{h})$ & 0.64 & 0.71 & 0.76 \\
\hline 8 & Performance index & 132 & 128 & 123 \\
\hline
\end{tabular}

\section{Conclusions}

Among 3 types of blades (2, 4, 6 blades per flange) 6 blades have maximum weeding efficiency, less plant damage and maximum depth of cut was $(85.2 \%, 3.30 \%$ and $4.60 \mathrm{~cm})$. From the study it can be concluded that the power weeder with 6 blades was preferred for weeding.

\section{References}

1. Ambujam. Evaluation of power weeder performance. Agricultural Mechanization in Asia, Africa and Latin America. 1993; 24:16.

2. Anonymous. Indian Council of Agricultural Research (Vision 2030), 2011.

3. Kepner RA, Bainer R, Barger EL. Principles of Farm Machinery, $3^{\text {rd }}$ edition, CBS Publications and Distributors New Delhi, 1978.

4. Fanoll. Evaluation of power weeder performance. Agricultural Mechanization in Asia, Africa and Latin America. 1993; 24:16.

5. Kumar NT, Kumar ST, Madhusudan NA, Ramya V. Performance evaluation of weeders. International Journal of Science, Environment and Technology. 2014; 3:21602165.

6. Srinivas I, Adake RV, Reddy BS, Korwar GR, Thyagaraj CR, Dange A et al. Comparative performance of different power weeders in rain fed sweet sorghum crop. Indian Journal of Dry land Agriculture Research and Development. 2010; 25:63-67.

7. Rangasamy K, Balasubramanian M, Swaminathan KR. Evaluation of power weeder performance. Agricultural Mechanization in Asia, Africa and Latin America. 1993; 24:16-18.

8. Tajuddin A. Design, development and testing of engine operated weeder, Agricultural Engineering Today. 2006; 30:25-29.

9. Yadav R, Pund S. Development and ergonomic evaluation of manual weeder. Agricultural Engineering International: The CIGR E Journal. 2007; 9:1-9. 